Almost 8,000 scientists, including 32 Nobel laureates, have signed a "personal moratorium" pledge in support of Andrei Sakharov, Yurii Orlov and Anatolii Shcharanskii, it was announced last week. The moratorium pledge was organized by the "SOS" campaign - original "Scientists for Orlov and Shcharanskii" but extended in January to include Sakharov on his exile to Gor'kii. All three were linked with the work of the Helsinki Watch Committee.

The pledge, which replaces an earlier "personal boycott", binds the signatories not to visit the Soviet Union nor to receive Soviet scientists in their laboratories from 15 May 1980 (the second anniversary of the Orlov trial) until the end of the forthcoming Madrid review conference on the progress of the Helsinki process - unless, in the meantime, Orlov and Shcharanskii are released from labour camp and Sakharov is restored to full liberty, including the right of residence in Moscow. A total of 6,100 scientists and engineers in 44 countries have signed the SOS pledge, while similar but independent pledges in France and Switzerland have so far attracted 1,200 and 600 signatures respectively.

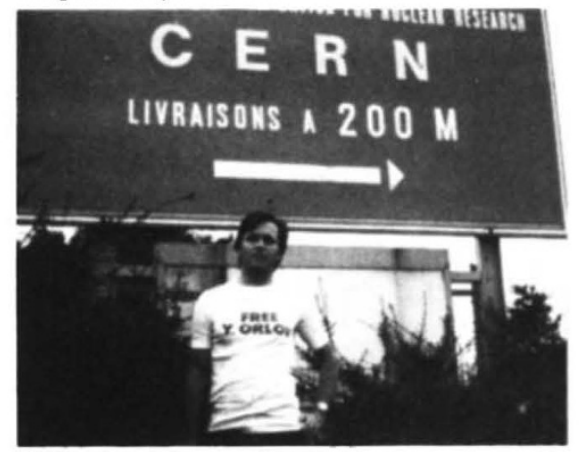

Orlov tee-shirts on show

The organizers now plan to deliver an information dossier to the delegations of the 33 countries signatory to the Helsinki Final Act before the conference officially opens on 11 November.

According to Dr John Charap (Queen Mary College, London) who took the chair at a meeting in London last week to report progress, the moratorium and previous boycott pledges have significantly cut Soviet exchanges with the West. In 1979, he said, short-term US-USSR exchanges of personnel had numbered 783 US and 662 Soviet scientists. In the first half of 1980 , partly as a result of the pledges, these figures had fallen to a mere 72 US and 117 Soviet scientists.

Since the pledges are essentially personal, it is impossible, of course, to stop Soviet scientists visiting Western establishments, even if there has been a large response to the campaign by the scientists employed there. CERN, for example, still receives a significant number of Soviet visitors, although a large number of the scientists there have organized and signed their own pro-Orlov moratorium. Here, the signatories to the pledge simply refuse

\section{Ariane failure known}

A faulty fuel injector in one of four rocket motors led to the failure of the second launch of the European Ariane rocket on 23 May this year.

This is the conclusion reached by the European Space Agency, which said last week that the fault caused the rate of burning fuel in the engine to oscillate 2,000 times per second soon after the launching.

A review group of independent experts has recommended that the Sociéte Europeen de Propulsion (SEP), which built the engines, should make future injectors to finer tolerances, and select good ones by ground firing tests before they are fitted to a launch vehicle.

The injector mixes fuel with oxidant at the top of the engine. It consists of a cylinder equal in diameter to the engine, with 5 -cm-thick walls pierced by hundreds of angled holes which direct streams of oxidant onto streams of fuel. Variations, within manufacturing tolerances, of the geometry of the holes seem to be capable of inducing instabilities in the burn - although the fluid dynamics of this is still not understood.

Experiments with engines at SEP in Vernon, near Paris, showed up the fault. Apparently, manufacturing tolerances have slipped since the 200 test firings, although with hindsight low amplitude oscillations have now been discovered in the data.

The third launch - with ground-tested injectors - is now scheduled for midMarch 1981. The fourth and last test flight would be in June 1981, and the first operational flight in October the same year, if all now goes well. The programme would then proceed with the dates planned before the failure of the second launch.

Robert Walgate

to conduct the visitors around their laboratories. When such visitors are expected at CERN, laboratory walls and notice boards display posters bearing simply Orlov's photograph and name, while many staff don T-shirts with the slogan "FreeY. Orlov".

The organizers of the moratoria emphasize that they are not "cold warriors". Nobel laureate H. Christian Anfinsen of the US National Institutes of Health said last week "We have traditionally pushed for togetherness but now we are deciding to hold back because of our concern for human rights"'.

All moratoria so far have been partial. They do not bind the participants, for example, not to speak to Soviet scientists at international conferences outside the Soviet Union, or not to correspond with Soviet colleagues. Several signatories report tacit sympathy for the campaign among Soviet scientists.

What the organizers hope for is not, however, entirely clear. They stress the harm that Soviet science will suffer, although the Soviets, in their turn, stress that Soviet science is self-sufficient and that moratoria can only harm the West. Dr Charap said last week that the Soviet government needs Western contacts in order to build up its economy, and that such contacts and exchanges are dealt with under "Basket two" of the Helsinki accords. If the Soviet Union wishes to benefit under "'Basket two", he said, it must be prepared also to implement "Basket three", which deals with human rights.

The Western attitude to the Helsinki Final Act has always been that the detente process is indivisible, while the Soviets have preferred to deal separately with the three "Baskets" and especially "Basket one" (arms control). The public speaking of the moratorium organizers is intended to stiffen the Western stand at Madrid on the human rights issue.

Last week's simultaneous meetings in London, Washington, Geneva and Paris were, however, timely for another reason. A few days before, Shcharanskii's mother, Mrs Ida Milgrom, reported that her son had collapsed on 23 September in his Perm labour camp and had been rushed to the prison hospital for emergency treatment of abdominal pains. And in London, John McDonald, QC, announced that Orlov had been put into the punishment area of his labour camp in the Urals, apparently for complaining that he was not receiving his mail and that the guards, drunk on duty, had beaten him up. His right to a visit from his wife this August was withdrawn, and she will not now be able to see him until August 1981. However, said $\mathrm{Mr}$ McDonald, Mrs Orlova is afraid that her 57-year-old husband will be unable to survive the present six months punishment regime.

Vera Rich

\section{Soviet science}

\section{Relations forsworn}

Old wounds will be opened at the salt domes of Gorleben, Lower Saxony, early next year when a new inquiry begins on the disposal of spent nuclear fuel. But this time it will not be a staged confrontation, as happened last May, of nuclear and nonnuclear experts. Now the licensing authority, the Physicalisch-Technische Bundesanstalt of Braunschweig, will present the case from the platform and protesters will have to speak from the floor. And protesters will not be getting financial support from the state.

The previous inquiry led to the rejection of the proposals, for reasons which the prime minister of Lower Saxony, Herr Albrecht, insists were political, not technical. The plan then was for a final disposal facility for all West German nuclear waste, but this has now become a plan for the temporary storage of up to 1,500 tonnes of spent fuel in transport con- 